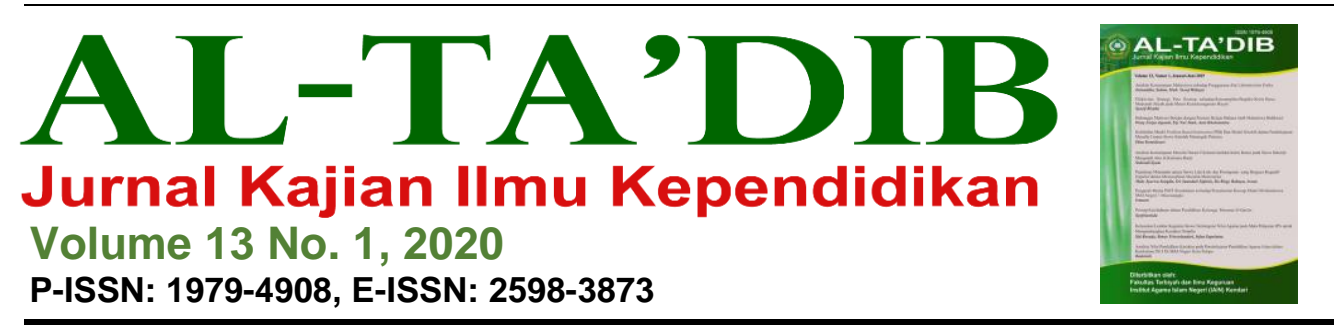

\title{
Evaluasi Pelaksanaan Standar Produk Hasil Belajar pada Satuan Pendidikan Anak Usia Dini
}

\section{La Ode Anhusadar ${ }^{1}$}

${ }^{1}$ Institut Agama Islam Negeri Kendari, Indonesia. Email: sadar.wanchines@gmail.com

\section{INFORMASI ARTIKEL}

Kata Kunci:

Evaluasi; standar

PAUD; standar produk

Cara Mensitasi:

Anhusadar, L. O. (2020).

Evaluasi pelaksanaan

standar produk hasil

belajar di satuan

pendidikan anak usia dini.

Al-Tadib, 13(1), 34-45

DOI:

\begin{tabular}{l} 
ABSTRAK \\
\hline Penelitian ini dilakukan dengan tujuan untuk \\
mengevaluasi pencapaian hasil belajar yang telah \\
ditetapkan berdasarkan standar produk pada satuan \\
pendidikan anak usia dini. Metode penelitian yang \\
digunakan dalam penelitian ini adalah metode \\
evaluasi model CIPP dengan pendekatan kualitatif. \\
Data dikumpulkan melalui observasi di lapangan, \\
wawancara terhadap guru dan kepala sekolah, dan \\
dokumentasi. Hasil penelitian mengungkapkan bahwa \\
pelaporan hasil belajar anak sudah menyertakan \\
seluruh aspek pengembangan anak. Pelaporan dibuat \\
dalam bentuk narasi berdasarkan rekapitulasi jumlah \\
angka yang diperoleh anak dalam penilaian harian. \\
Kelemahan penilaian semacam ini adalah kurangnya \\
fakta berupa laporan atau catatan tertulis tentang \\
kemajuan anak sebagai dasar membuat laporan akhir.
\end{tabular}


ARTICLE INFO

Keywords:

Evaluation; product standard; PAUD standard

How to cite:

Anhusadar, L. O. (2020).

Evaluasi pelaksanaan

standar produk hasil

belajar di satuan

pendidikan anak usia dini.

Al-Tadib, 13(1), 34-45

DOI:

\section{ABSTRACT}

This reasearch aims to evaluate the learning outcome based on the product standard at playgroup level. Using CIPP model as research design, data were gathered from observation, interview with the teachers and headmaster, and documentation. The results of this study reveals that children's learning outcomes have included all aspects of child development. Children's report is made in form of narrative based on the recapitulation of figures of their daily assessments. The weakness of this kind of assessment is the lack of factual description in the form of report or notes about the child's progress as a basis for making the final report.

\section{Pendahuluan}

Peningkatan jumlah lembaga pendidikan anak usia dini (PAUD) di tiap daerah mengalami peningkatan jumlah dari tahun ke tahun. Peningkatan ini juga dapat dilihat dari jumlah lembaga PAUD yang ada di kabupaten Wakatobi yang mengalami peningkatan. Data online tahun 2020 dari website Sistem Informasi Aplikasi Pendidikan (SIAP) Dinas Pendidikan Kabupaten Wakatobi menunjukkan jumlah lembaga PAUD yang berstatus negeri sebanyak tiga lembaga dan yang berstatus swasta sebanyak 89 lembaga (SIAP, 2020). Peningkatan jumlah lembaga PAUD tersebut menjadi sebuah indikator semakin membaiknya perhatian dan pemahaman masyarakat setempat terhadap pentingnya pendidikan anak usia dini bagi anak-anak mereka.

Peningkatan lembaga PAUD ini juga harus memperhatikan kualitas sehingga tumbuh kembang anak bisa lebih ditingkatkan. Selain itu, kualitas pendidik PAUD juga harus diperhatikan sehingga metode pembelajaran berfokus pada keaktifan anak dalam proses pembelajaran. Keterbatasan sarana dan prasarana PAUD serta ketersediaan dan penggunaan bahan ajar dan media pembelajaran kadang masih menjadi masalah. Kualifikasi pendidikan dari pendidik PAUD juga masih menjadi masalah yang berdampak pada kualitas sumber daya manusia karena sering ditemukan pendidik PAUD dengan kualifikasi tamatan SMA atau sederajat.

Selama ini tolak ukur evaluasi pelaksanaan program di lembaga PAUD adalah akreditasi, tetapi belum semua lembaga PAUD sudah terakreditasi. Selain itu, instrumen akreditasi PAUD yang dibuat oleh badan akreditasi nasional (BAN) PAUD dan PNF masih memiliki beberapa kelemahan, seperti butir instrumen dan indikator yang masih terbatas. Kondisi yang dipaparkan tersebut tidak diharapkan berlangsung dalam waktu yang lama. Pihak lembaga 
PAUD dan pemerintah yang diwakili oleh Dinas Pendidikan setempat perlu mengatasi kondisi yang ada guna perbaikan mutu dan peningkatan kualitas sekolah dan peserta didik. Peran terberat pemerintah daerah dan lembaga PAUD saat ini adalah memberikan pelatihan untuk pendidik PAUD dan memastikan mereka memiliki kemampuan minimal, sehingga dimana pun mereka mengajar, apapun bentuk satuan pendidikannnya, mereka dapat menguasai prinsip-prinsip dasar mengajar. Evaluasi terhadap pelaksanaan standar PAUD penting untuk dilakukan untuk mengetahui sejauh mana efektifitas standar PAUD dalam penyelenggaran program PAUD di sekolah. Untuk itu, penting untuk mengembangkan model evaluasi program layanan PAUD yang komprehensif dan akurat.

Anak usia dini masuk dalam kategori yang berusia di bawah enam tahun yang sedang pesat pertumbuhannya dan perkembangannya baik fisik maupun psikis. Menurut Husein, dkk. (dalam Sumantri, 2005), anak usia dini berada pada masa lima tahun pertama yang disebut The Golden Age. Masa ini merupakan masa emas perkembangan anak. Perkembangan otak anak yang sedang tumbuh melalui tiga tahapan, mulai dari otak primitif (action brain), otak limbik (feeling brain), dan akhirnya ke neocortex (atau disebut juga thought brain atau otak pikir) (Anhusadar, 2018). Pada periode ini, hampir seluruh potensi anak mengalami masa peka untuk tumbuh dan berkembang secara cepat. Apabila anak mendapatkan stimulus yang baik maka seluruh aspek perkembangan anak akan berkembang secara optimal. Salah satu aspek yang penting untuk dikembangkan adalah aspek perkembangan motorik, terutama motorik halus. Anak usia dini merupakan dasar awal yang menentukan kehidupan suatu bangsa di masa yang akan datang, sehingga diperlukan persiapan generasi penerus bangsa dengan mempersiapkan anak untuk tumbuh dan berkembang secara optimal baik dalam perkembangan moral, fisik/motorik, kognitif, bahasa, maupun sosial emosional. Setiap anak berhak untuk mendapatkan penghidupan dan perlindungan yang layak, serta dapat tumbuh dan berkembang secara optimal (Anhusadar \& Islamiyah, 2019).

PAUD merupakan jenjang pendidikan yang diselenggarakan untuk mengembangkan keterampilan yang merupakan pendidikan dasar serta mengembangkan diri secara utuh sesuai dengan asas pendidikan sedini mungkin dan sepanjang hayat. Aspek yang dikembangkan dalam PAUD adalah aspek pengembangan pembiasaan meliputi sosial, emosi, kemandirian, moral, dan nilai-nilai agama, serta pengembangan kemampuan dasar yang meliputi pengembangan bahasa, kognitif, dan fisik motorik (Musfiroh, 2008). Salah satu bentuk lembaga PAUD yang berada pada jalur formal adalah taman kanak-kanak (TK) dengan rentang usia siswa 5-6 tahun. Tujuan pendidikan di TK untuk pencapaian perkembangan nilai agama dan moral, fisik motorik kasar, motorik halus, kesehatan fisik, serta kognitif. Aspek kognitif meliputi pengetahuan umum dan sains, konsep bentuk warna ukuran dan pola, konsep 
bilangan lambang bilangan dan huruf, bahasa yaitu menerima bahasa, mengungkapkan bahasa, keaksaraan, dan sosial emosional.

Anak usia dini mengalami pertumbuhan dan perkembangan yang sangat pesat sehingga membutuhkan stimulasi yang sesuai dengan kebutuhan anak-anak. Stimulasi tersebut salah satunya dapat diperoleh dari PAUD. PAUD merupakan upaya pembinaan dan melalui pemberian rangsangan pendidikan untuk membantu pertumbuhan dan perkembangan jasmani dan rohani agar anak dapat memiliki kesiapan dalam memasuki pendidikan lebih lanjut (Suyadi, 2010). Kreativitas anak usia dini dapat diupayakan melalui permainan yang dirancang oleh pendidik di lembaga PAUD karena dengan permainan anak dapat mengembangkan serta mengintegrasikan semua potensinya sehingga mereka lebih kreatif. Peran pendidik dalam kegiatan permainan anak adalah memberikan dorongan, membimbing bermain bagi anak dan membantu anak mengembangkan potensinya, sehingga mereka menjadi anak yang kreatif (Anhusadar, 2016).

Kompetensi pendidik PAUD dalam merancang model pembelajaran yang inovatif berbasis kearifan budaya lokal dapat dideskripsikan sebagai berikut: 1) pendidik sudah menentukan tema pembelajaran yang sesuai dengan potensi lokal; 2) tema yang dipilih sudah berbasis kearifan budaya lokal; 3) adanya kesesuaian antara indikator dengan materi pembelajaran; 4) adanya kesesuaian antara tema dengan kegiatan pembelajaran; 5) adanya keterpaduan antara materi pembelajaran dengan kegiatan pembelajaran yang dilakukan anak; dan, 6) media pembelajaran atau alat peraga edukatif (APE) sudah memanfaatkan potensi budaya lokal (Munawar, Prasetyo, \& Pusari, 2013).

Pelaksanaan proses belajar pada PAUD perlu dilakukan pengembangan mengingat pentingnya masa golden age. Evaluasi pada bagian pelaksanaan pembelajaran umumnya menunjukkan hasil yang kurang maksimal jika dibandingkan dengan aturan dalam standar PAUD. Misalnya, setiap lembaga PAUD sudah menerapkan penataan lingkungan ruang kelas dan pengorganisasian kegiatan, akan tetapi sebagian masih terkesan kaku. Kasrani (2016) melaporkan bahwa rata-rata lembaga PAUD mempunyai ruang kelas yang sudah ditata secara permanen, yaitu area dan peralatan telah ditetapkan pada lokasi masing-masing dengan maksud tidak akan berubah lagi pada kegiatan belajar sampai anak didik menyelesaikan program belajarnya di PAUD. Buku laporan penilaian perkembangan anak menggunakan format buku laporan yang dikeluarkan oleh dinas pendidikan Kabupaten.

Terkait laporan pendidikan anak, ada beberapa tahapan yang dikerjakan guru dalam membuat laporan hasil belajar anak. Pertama, guru melakukan penilaian harian lalu menulis hasilnya di dalam buku rencana kegiatan harian (RKH). Kedua, guru memindahkan catatan penilaian harian ke buku rekapitulasi. Ketiga, guru melakukan analisa perkembangan anak per individu berdasarkan hasil rekapitulasi jumlah bintang yang diperoleh anak. 
Keempat, guru memindahkan hasil analisa ke dalam buku rapor. Kelima, guru menyerahkan buku laporan anak kepada orang tua peserta didik.

Evaluasi telah dilakukan oleh semua lembaga PAUD, walaupun masih ada instrumen evaluasi pembelajaran yang bervariasi. Ada beberapa lembaga yang memiliki instrumen evaluasi lengkap dan ada yang masih kurang lengkap. Selain itu, pengawasan pembelajaran PAUD oleh kepala satuan PAUD atau penilik dari dinas pendidikan telah dilaksanakan secara berkala. Hasil penelitian Felayati dan Yaswinda (2019) menemukan bahwa kegiatan proses pembelajaran di lembaga PAUD di lokasi penelitian mereka umumnya telah menggunakan Standar Isi Tentang Tingkat Pencapaian Perkembangan Anak (STTPPA) sebagai acuan. Sedangkan kurikulum yang telah dilaksanakan telah meliputi pelaksanaan pembelajaran berdasarkan program muatan kurikulum, kompetensi inti, kompetensi dasar dan lama belajar yang telah disusun dan dilaksanakan. Penelitian tersebut menemukan bahwa upaya pelaksanakan kurikulum 2013 dan pembelajaran menggunakan STTPPA telah terlaksana dengan baik.

Akan tetapi, perencanaan pembelajaran belum menjamin kesuksesan proses pembelajaran karena proses penyampaian atau pengimplementasian dari rencana yang menentukan efektivitas dari suatu proses pembelajaran. Oleh karena itu, terkait evaluasi proses, masih ada lembaga belum memenuhi standar PAUD sepenuhnya. Seperti yang ditemukan dalam penelitian Felayati dan Yaswinda (2019), penyusunan Rencana Pelaksanaan Pembelajaran Mingguan (RPPM) dan Rencana Pelaksanaan Pembelajaran Harian (RPPH) kadang belum dilakukan secara maksimal dan tertib karena pendidik merasa sudah memiliki RPPM dan RPPH yang sudah jadi dan kurang dimodifikasi. Selain itu, jika peserta didik terlalu lama mengerjakan atau bahan pembelajaran tidak tersedia, maka tidak jarang RPPH yang telah dibuat jadi bergeser.

Dalam penelitian yang dilakukan Utami, Jamaris dan Meilanie (2019), mereka menemukan bahwa perkembangan anak pada dua lembaga PAUD yang mereka teliti cukup berkembang dengan baik. Kedua lembaga menggunakan berbagai macam teknik penilaian penilaian perkembangan anak didik. Semua partisipan telah cukup baik memenuhi indikator pencapaian perkembangan. Walaupun dengan kegiatan yang masih monoton, pendidik terus membantu meningkatkan perkembangan anak yang belum memenuhi indikator pencapaian perkembangan. Hal ini perlu terus ditingkatkan oleh pihak sekolah karena hasil penilaian perkembangan anak sebagai salah satu cermin keberhasilan sekolah dalam mewujudkan visi dan misi sekolah. Sementara itu, terkait masalah input dan proses, penelitian Hermawati (2007) di tempat penitipan anak (TPA) di Yogyakarta menemukan dua kelemahan dari variabel input, yaitu kualifikasi pendidikan pengajar dan pengasuh yang tidak relevan dengan bidang tugas. Pada variabel proses, masalah yang ditemukan adalah belum terukurnya kegiatan pendampingan oleh pengasuh. 
Hal ini terkait dengan pendidikan pengasuh yang lebih rendah dari yang disyaratkan. Selain itu, pendampingan secara teratur belum dilakukan oleh penyelenggara dan akses masyarakat terhadap TPA terbatas karena daya tampung yang tidak memadai.

Dalam evaluasi proses lembaga PAUD, kegiatan-kegiatan yang direncanakan seyogyanya terlaksana dengan baik dengan penyesuaian kegiatan sesuai kondisi dan kebutuhan. Kendala yang ada, baik dari guru, kepala sekolah, manajemen sekolah, maupun sarana-prasarana, harus dapat ditangani dengan baik agar kesiapan dan partisipasi kepala sekolah maupun para guru mendukung pelaksanaan program supervisi akademik. Dokumentasi yang lengkap dan terstruktur terhadap kegiatan yang telah dilakukan lebih ditingkatkan. Guru perlu meningkatkan ketersediaan sarana mengajar dan variasi belajar anak dengan cara menyiapkan materi belajar yang vaiatif sesuai dengan tema belajar agar anak tidak bosan dan dapat belajar banyak hal. Dalam evaluasi pada tataran produk, laporan hasil belajar anak harus sesuai dengan tingkat pencapaian perkembangan anak yang diatur dalam standar PAUD. Artinya, tiap aspek pengembangan anak dijelaskan tingkat ketercapaiannya. Hasil penelitian yang dilakukan oleh Anamara (2014) menemukan bahwa ada kelemahan terkait cara melakukan penilaian yang digunakan pada TK yang diteilitinya. Perkembangan semua peserta didik dicatat secara general atau menggabungkan antara anak yang satu dengan yang lainnya. Padahal, setiap peserta didik memiliki ciri atau karakter yang berbeda satu sama satu lain, sehingga mencatat secara individu akan membantu pendidik dalam menilai anak secara lebih mendalam.

Pemerintah telah berupaya mengatasi masalah kualitas lembaga PAUD tersebut dengan mengeluarkan Peraturan Menteri Pendidikan Nasional No. 58 tahun 2009 yang kemudian disempurnakan melalui Peraturan Menteri Pendidikan dan Kebudayaan No. 137 tahun 2014 tentang standar PAUD. Peraturan ini memuat delapan standar, yaitu: standar tingkat pencapaian perkembangan anak, standar isi, standar proses, standar penilaian, standar pendidikan dan tenaga kependidikan, standar sarana dan prasarana, standar pengelolaan dan standar pembiayaan. Standar PAUD tersebut diharapkan menjadi standar acuan minimal bagi masyarakat dan pemerintah untuk memberikan pelayanan pendidikan yang berkualitas bagi anak usia dini. Akan tetapi, dalam pelaksanaannya masih banyak yang tidak sesuai dengan peraturan tersebut. Masalah ini juga ditemukan di lembaga PAUD yang ada di kabupaten Wakatobi. Dari segi standar pendidikan, masih banyak pendidik PAUD yang tidak sesuai dengan kualifikasi pendidikan yang disyaratkan. Dari segi standar isi, kurikulum berganti hanya nama saja tetapi isinya tetap sama. Dari segi standar tingkat pencapaian perkembangan anak, pihak sekolah belum membuat perencanaan dan kegiatan pembelajaran sesuai dengan kebutuhan dan minat anak. Sedangkan dari segi standar penilaian perkembangan peserta 
didik, guru masih melakukan pencatatan seadanya tanpa menggunakan format yang baik.

\section{Metode Penelitian}

Metode penelitian yang digunakan dalam penelitian ini adalah metode evaluasi model context, input, process, dan product (CIPP) dengan pendekatan kualitatif. Model evaluasi CIPP dikembangkan oleh Daniel Stufflebeam pada tahun 1966. Stufflebeam menyatakan model evaluasi CIPP merupakan model evaluasi komprehensif yang memiliki fungsi formatif dan fungsi sumatif. Fungsi formatif evaluasi adalah memberikan informasi guna memperbaiki dan mengembangkan program, sedangkan fungsi sumatif evaluasi adalah memberi pertimbangan untuk menentukan keberhasilan atau kelanjutan program (Jaya \& Ndeot, 2018).

Dalam artikel ini, penulis fokus pada pemaparan hasil investigasi evaluasi produk hasil belajar di sebuah kelompok bermain di salah satu kecamatan di Kabupaten Wakatobi, Sulawesi Tenggara. Kelompok Bermain (Kober) Cahaya (nama disamarkan) merupakan salah satu lembaga yang memiliki siswa terbanyak di daerah sekitarnya. Kelompok bermain ini sudah berdiri selama kurang lebih sepuluh tahun. Salah satu alasan didirikannya Kober ini karena masih banyak anak usia dini di daerah tersebut yang belum masuk ke lembaga PAUD. Selain itu, banyak orang tua yang meminta agar lembaga PAUD didirikan di daerah tersebut. Pada awalnya, Kober Cahaya memiliki bangunan di atas laut dan terbuat dari papan sehingga untuk dapat masuk ke dalam lingkungan sekolah, peserta didik harus ditemani oleh orang tuanya melewati jembatan yang terbuat dari bambu. Seiring berjalannya waktu, pada tahun 2015, bangunan kober ini sudah dibangun setengah permanen dan jembatan bambu diganti dengan papan.

\section{Tabel 1. Penelitian evaluasi produk hasil belajar}

\begin{tabular}{lll}
\hline No & \multicolumn{1}{c}{$\begin{array}{c}\text { CIPP } \\
\text { (Produk) }\end{array}$} & Permendikbud No. 137 Tahun 2014 \\
\hline & & Standar tingkat pencapaian PAUD, \\
1 & Hasil Belajar & $\begin{array}{l}\text { Standar proses dan } \\
\text { Standar penilaian }\end{array}$ \\
& & \\
&
\end{tabular}

Evaluasi produk menurut Stufflebeam adalah "product evaluation identify intended and unintended outcomes both to help keep the process on track and determine effectiveness" (Stufflebeam \& Zhang, 2017). Evaluasi produk berguna untuk mengidentifikasi hasil yang diinginkan dan tidak diinginkan, untuk membantu menjaga keefektifan sebuah proses. Popham 1975) menjelaskan bahwa proses evaluasi adalah untuk mengidentifikasi 
kecacatan dalam desain prosedural. Popham (1975) mengemukakan "product evaluation attempts to measure and interpret the attainments yielde by an instructional program not only at its conclusion but, as often as necessary, during the program it self".

Selanjutnya Gall, Borg, dan Gall (1996) menyatakan bahwa evaluasi produk dilakukan untuk menentukan sejauh mana ketercapaian tujuan program. Sementara itu, Arikunto (2004) mengemukakan bahwa evaluasi produk mengarah pada hal-hal yang menunjukkan perubahan yang terjadi setelah pelaksanaan program. Sedangkan Mulyatiningsih (2014) menegaskan bahwa evaluasi produk bertujuan untuk mengukur, megniterpretasikan dan memutuskan hasil yang telah dicapai oleh program apakah telah memenuhi kebutuhan sesuai dengan tujuan yang diharapkan. Lebih lanjut, Wirawan (2012) menjelaskan evaluasi produk berupaya untuk mengidentifikasi dan mengakses keluaran dan manfaat, baik yang direncanakan atau tidak direncanakan, baik jangka pendek maupun jangka panjang. Merujuk dari beberapa pendapat tersebut di atas dapat disimpulkan bahwa evaluasi produk merupakan tahap akhir dari model evaluasi CIPP yang betujuan untuk mengukur, menginterpretasikan dan memutuskan hasil yang telah dicapai oleh program, apakah sudah dapat memenuhi standar atau kebutuhan sesuai dengan tujuan yang diharapkan

\section{Hasil dan Pembahasan}

Evaluasi produk adalah evaluasi yang dilakukan untuk mengukur keberhasilan pencapaian hasil belajar yang telah ditetapkan. Dengan kata lain, evaluasi produk mengakomodasi informasi untuk meyakinkan dalam kondisi apa tujuan dapat dicapai dan juga untuk menentukan jika strategi yang berkaitan dengan prosedur dan metode yang diterapkan guna mencapai tujuan sebaiknya dihentikan, dimodifikasi atau dilanjutkan. Dalam konteks implementasi standar PAUD, maka produk yang hendak dilihat adalah laporan hasil belajar peserta didik anak usia dini di sekolah untuk mengetahui apakah laporan hasil belajar yang dibuat telah sesuai dengan perkembangan yang ditetapkan atau belum sesuai.

Kober Cahaya memiliki buku laporan perkembangan anak yang dikeluarkan oleh dinas pendidikan setempat, sehingga pengisian hasil belajar anak mengacu pada buku laporan ini. Hasil belajar anak yang dilaporkan meliputi seluruh aspek perkembanqan anak sebagaimana diatur dalam standar PAUD. Aspek yang dilaporkan dalam laporan yang di kober ini ada dua hal. Pertama, pembiasaan, yang terdiri atas komponen moral dan nilai-nilai agama, sosial emosional, serta kemandirian. Kedua, kemampuan dasar, yang meliputi komponen bahasa, kognitif, fisik/motorik, dan seni. Pelaporan hasil belajar anak di kober ini melalui empat tahapan, yakni: (1) guru melakukan rekapitulasi hasil penilaian harian dengan cara menjumlahkan angka yang 
diperoleh peserta didik; (2) hasil rekapitulasi yang diperoleh kemudian dianalisis pada kertas kerja; (3) membuat narasi berdasarkan analisis; dan, (4) menuangkan dalam rapor. Hal ini sebagaimana dijelaskan Ibu $\mathrm{R}$ dalam wawancara bahwa setelah membuat rangkuman penilaian dan analisis "kami tuangkan lagi ke kalimat narasi dan kemudian ke dalam rapor. Rapor itu diserahkan ke orang tua pada bulan Juni dan Desember. Poin yang dianalisis dilihat di rangkuman penilaian, poin-poin itu ada yang 1-4 poin" (Wawancara, 29 Agustus 2019).

Informasi dari Ibu R diperkuat oleh bu W. Namun, menurutnya, proses pembuatan laporan yang demikian membutuhkan waktu dan sulit karena guru lebih menyukai pelaporan menggunakan angka daripada narasi sebagaimana dituturkan bahwa "penilaian itu dalam rapor bukan nilai ABC tapi angka. Itu bagus tapi kerjanya setengah mati. Analisis kita kemudian masuk per anak" (Wawancara, 29 Agustus 2019). Selanjutnya, laporan yang telah dinarasikan ke dalam buku rapor akan diberikan kepada orang tua murid setiap enam bulan. Jika hasil capaian anak belum sesuai, maka pihak sekolah yang diwakili guru kelas biasanya akan menyampaikan secara langsung kepada orang tua murid saat pembagian rapor untuk mencari solusi bersama.

Komponen-komponen pengembangan yang dibahas dalam program analisis hasil belajar anak meliputi lima poin. Pertama, pembentukan perilaku, meliputi nilai-nilai agama dan moral, sosial emosional, dan kemandirian. Kedua, kemampuan dasar, meliputi bahasa yakni menerima dan mengungkapkan bahasa dan keaksaraan. Ketiga, kognitif, meliputi pengetahuan umum sains, konsep bentuk, warna, ukuran, dan pola. Keempat, konsep bilangan, lambang bilangan dan huruf. Kelima, fisik, meliputi motorik kasar, motorik halus dan kesehatan fisik. Dari komponen-komponen evaluasi yang sudah dipaparkan, akan lebih mudah untuk mengetahui hasil studi ini dengan membandingkan secara ringkas antara hasil evaluasi dengan standar PAUD.

Evaluasi pada tataran ini memperlihatkan bahwa laporan hasil belajar anak dilaporkan sesuai dengan tingkat pencapaian perkembangan anak yang diatur dalam standar PAUD. Artinya, tiap aspek perkembangan anak dijelaskan tingkat ketercapaiannya. Namun, masih ada kelemahan terkait cara melakukan penilaian yang digunakan kober dalam penelitian ini. Perkembangan semua peserta didik dicatat secara general atau dengan kata lain digabungkan antara anak yang satu dengan yang lainnya. Padahal, setiap peserta didik memliki karakter yang berbeda satu sama yang lain sehingga mencatat secara individu akan membantu pendidik dalam menilai anak secara lebih mendalam.

Pendidik seharusnya mengetahui bahwa pencapaian peserta didik bukan semata-mata mencatat anak mengalami perkembangan setelah berada di lembaga PAUD. Lebih dari itu, Basford dan Wood (2018) berpendapat bahwa 
hasil penilaian memberi masukan menyangkut pertumbuhan dan perkembangan anak. Hal yang tak kalah penting adalah pihak lembaga mendapat informasi apakah peserta didik membutuhkan akses terhadap material/alat permainan edukatif (APE) yang dapat menolong anak yang bermasalah dalam pelajaran dan perkembangannya. Basford dan Wood (2018) bahkan menekankan bahwa penilaian mempunyai arti penting selain menilai performance anak secara individual. Penilaian juga dapat memberi informasi tentang kualitas program atau efektifitas suatu kegiatan pembelajaran. Hal ini yang belum dilakukan oleh Kober Cahaya karena sekolah menganggap bahwa pembelajaran yang dilaksanakan merupakan suatu kegiatan yang sudah baku bagi lembaga PAUD.

Di Kober Cahaya, buku laporan penilaian perkembangan anak memakai format buku laporan yang dikeluarkan dinas pendidikan kabupaten. Ada beberapa tahapan yang dikerjakan para guru dalam membuat laporan hasil belajar anak. Pertama, guru menulis penilaian harian dalam buku rencana kegiatan harian/RPPH. Kedua, guru memindahkan catatan penilaian harian ke buku rekapitulasi. Ketiga, guru melakukan analisa perkembangan anak per individu berdasarkan hasil rekapitulasi jumlah angka yang diperoleh anak. Keempat, guru memindahkan hasil analisa ke dalam buku rapor. Kelima, guru menyerahkan buku laporan anak kepada orang tua peserta didik. Sebenarnya, penilaian semacam ini tidak memberikan gambaran yang cukup lengkap terhadap tingkat perkembangan anak karena guru tidak memiliki bukti atau dokumentasi yang cukup terkait capaian-capaian yang diperoleh anak. Penilaian seperti ini hanya sebatas memberikan angka, kemudian rekapitulasi yang diikuti dengan membuat narasi.

\section{Kesimpulan}

Dalam penelitian ini ditemukan bahwa pelaporan hasil belajar anak sudah menyertakan seluruh aspek perkembangan anak. Pelaporan dibuat dalam bentuk narasi berdasarkan rekapitulasi jumlah angka yang diperoleh anak dalam penilaian harian. Kelemahan penilaian semacam ini adalah tidak adanya cukup fakta berupa laporan atau catatan tertulis yang akan menjelaskan kemajuan anak sebagai dasar membuat laporan akhir.

\section{DAFTAR PUSTAKA}

Anamara, M. G. V. (2014). Evaluasi program implementasi standar PAUD. Jurnal Pendidikan Usia Dini, 8(2), 301-314. DOI: 10.21009/JPUD.082.010

Anhusadar, L. O. (2016). Kreativitas pendidikan di lembaga PAUD. Al-Ta'dib, 9(1), 76-93. 
Anhusadar, L. O. (2018). Perkembangan otak anak usia dini. Shautut Tarbiyah, $30,98-113$.

Anhusadar, L. O., \& Islamiyah, I. (2019). Taman layak anak usia dini di Kota Kendari. Jurnal Obsesi: Jurnal Pendidikan Anak Usia Dini, 3(1), 117. DOI: $10.31004 /$ obsesi.v3i1.143

Arikunto, S. (2004). Evaluasi program pendidikan. Jakarta: Bumi Aksara.

Basford, J., \& Wood, E. (2018). Assessment in early childhood education in England: Handbook of international perspectives on early childhood education. DOI: 10.4324/9781315562193-25

Felayati, \& Yaswinda. (2019). Penerapan model evaluasi CIPPO dalam mengevaluasi penyelenggaraan lembaga PAUD. Jurnal Obsesi: Jurnal Pendidikan Anak Usia Dini, 4(1), 30-40. DOI: 10.31004/obsesi.v4i1.238

Hermawati, I. (2007). Evaluasi program pendidikan anak usia dini (PAUD) bagi anak dari keluarga miskin di tempat penitipan anak (TPA) Beringharjo, Yogyakarta. Jakarta: Departemen Sosial RI, Badan Pendidikan dan Penelitian Kesejahteraan Sosial, Balai Besar Penelitian dan Pengembangan, Pelayanan Kesejahteraan Sosial.

Jaya, P. R. P., \& Ndeot, F. (2019). Penerapan model evaluasi CIPP dalam mengevaluasi program layanan PAUD holistik integratif. PERNIK: Jurnal Pendidikan Anak Usia Dini, 1(01), 10-25.

Kasrani. (2016). Evaluasi program pendidikan anak usia dini (PAUD). Manajemen Pendidikan, 25(2), 233-243.

Gall, M. D., Borg, W. R., \& Gall, J. P. (1996). Educational research: An introduction. Longman Publishing.

Mulyatiningsih. (2014). Evaluasi Program Pendidikan. Jakarta: Universitas Terbuka.

Munawar, M., Prasetyo, A., \& Pusari, R. W. (2013). Pengembangan model pembelajaran inovatif melalui pendekatan in house training berbasis kearifan budaya lokal. PAUDIA, 2(1), 1-13.

Musfiroh, T. (2008). Bermain sambil belajar dan mengasah kecerdasan. 
Jakarta: Depdiknas.

SIAP. (2020). Rekapitulasi data pendidikan di Kabupaten Wakatobi: TK/PAUD. Sistem Informasi Aplikasi Online Versi 2.0.0 Beta. Diakses dari http://wakatobi.siap-online.com

Stufflebeam, D. L., \& Zhang, G. (2017). The CIPP evaluation model: How to evaluate for improvement and accountability. New York: Guilford Publications.

Sumantri. (2005). Model pengembangan keterampilan motorik anak usia dini. Jakarta: Departemen Pendidikan Nasional.

Suyadi. (2010). Psikologi belajar PAUD. Yogyakarta: Pustaka Insan Madani.

Utami, W. Y. D., Jamaris, M., \& Meilanie, S. M. (2019). Evaluasi program pengelolaan lembaga PAUD di Kabupaten Serang. Jurnal Obsesi: Jurnal Pendidikan Anak Usia Dini, 4(1), 67-76. DOI: 10.31004/obsesi.v4i1.259

Popham, W. J. (1975). Educational evaluation. New Jersey: Prentice-Hall.

Wirawan. (2012). Evaluasi teori, model, standar, aplikasi dan proses. Jakarta: Rajawali Press. 